\title{
Entry
}

\section{Age-Friendly Built Environment}

\author{
Hing-Wah Chau *(1) and Elmira Jamei (1)
}

check for updates

Citation: Chau, H.-W.; Jamei, E. Age-Friendly Built Environment. Encyclopedia 2021, 1, 781-791. https:// doi.org/10.3390/encyclopedia1030060

Academic Editor: Antonio Frattari

Received: 6 June 2021

Accepted: 5 August 2021

Published: 10 August 2021

Publisher's Note: MDPI stays neutral with regard to jurisdictional claims in published maps and institutional affiliations.

Copyright: (c) 2021 by the authors. Licensee MDPI, Basel, Switzerland. This article is an open access article distributed under the terms and conditions of the Creative Commons Attribution (CC BY) license (https:// creativecommons.org/licenses/by/ $4.0 /)$.
Built Environment Discipline Group, Institute for Sustainable Industries and Liveable Cities,

College of Engineering and Science, Victoria University, Footscray, VIC 3155, Australia; elmira.jamei@vu.edu.au

* Correspondence: Hing-Wah.Chau@vu.edu.au

Definition: Age-friendly built environments have been promoted by the World Health Organisation (WHO, Geneva, Switzerland) under the Global Age-friendly Cities (AFC) movement in which three domains are related to the built environment. These are: housing, transportation, outdoor spaces and public buildings. The aim is to foster active ageing by optimising opportunities for older adults to maximise their independent living ability and participate in their communities to enhance their quality of life and wellbeing. An age-friendly built environment is inclusive, accessible, respects individual needs and addresses the wide range of capacities across the course of life. Agefriendly housing promotes ageing in familiar surroundings and maintains social connections at the neighbourhood and community levels. Both age-friendly housing and buildings provide barrier-free provisions to minimise the needs for subsequent adaptations. Age-friendly public and outdoor spaces encourage older adults to spend time outside and engage with others against isolation and loneliness. Age-friendly public transport enables older adults to get around and enhances their mobility. For achieving an age-friendly living environment, a holistic approach is required to enable independent living, inclusion and active participation of older adults in society. The eight domains of the AFC movement are not mutually exclusive but overlap and support with one another.

Keywords: age-friendly; active ageing; ageing in place; walkability; bikeability; accessibility

\section{Introduction}

The world population is growing older according to the World Population Prospects 2019 published by the United Nations. Persons aged 65 or above outnumbered children under five years old globally for the first time in history in 2018. One in eleven people in the world (9\%) were aged 65 or above in 2019, which is projected to increase to one in six people (16\%) by 2050 . This figure is even projected to be one to four (25\%) in Europe and North America by 2050. Lower birth rates and higher life expectancies are transforming the age pyramid shape, especially for developed countries. Another significant trend is urbanisation, which is projected to increase from $53 \%$ of people living in urban areas in 2020 to $70 \%$ in 2050 [1]. In response to the twin factors of population ageing and urbanisation, the World Health Organisation (WHO, Geneva, Switzerland) published Global Age-friendly Cities: A Guide (AFC Guide) in 2007 to enhance the age-friendliness of urban environments [2]. The demographic change towards a much older population structure has considerable consequences for the built environment, social welfare and community services. There is a framework of eight domains to enhance the age-friendliness of cities which can be classified into three categories: (1) the built environment to cover housing, outdoor spaces, public buildings and transportation; (2) social aspects to cover respect and social inclusion, employment, social and civic participation; and (3) service provisions to cover community support and health services, communication and information. The aim of this encyclopedic entry is to unfold the underlying idea of the AFC movement, highlight the importance of creating age-friendly built environments and provide recommendations.

The Global AFC movement can be traced back to the resolution 33/52 of the United Nations General Assembly on 14 December 1978 in which worldwide attention was called 
to the problems of ageing [3]. Subsequently, the First World Assembly on Ageing was held in Vienna in 1982, resulting in the Vienna International Plan of Action on Ageing with 62 recommendations for formulating relevant policies and programmes on ageing [4]. After 20 years, the Second World Assembly on Ageing was held in Madrid in 2002 to review the implementation of the previous Vienna International Plan and to release the Madrid International Plan of Action on Ageing which focused on three priority areas: older persons and development, advancing health and wellbeing into old age, and ensuring enabling and supportive environments [5].

As a contribution to the Second World Assembly on Ageing, the WHO published the Active Ageing: A Policy Framework in 2002 to formulate action plans that promote health and active aging [6]. The underlying idea of the AFC movement is the policy framework for active ageing. Active ageing aims to extend healthy life expectancy and enhance quality of life as people age. The word 'active' does not merely refer to physically active but also refers to the continual participation in social, economic, civil, cultural and spiritual affairs according to personal needs, desires and capabilities. Active ageing arouses people's awareness of their social, physical and mental wellbeing and highlights the importance of maximising autonomy, mobility and engagement. On one hand, maintaining independence to make personal decisions in relation to daily living based on own preferences is a key goal; on the other hand, maintaining social interaction including intergenerational relationships for older adults is crucial as ageing takes place within the context of others, including friends, neighbours and family members. Since the decline in personal abilities and skills vary from a life course perspective, the supportive and enabling living environments promoted by the age-friendly city movement thus do not only cater for older adults but also address the needs of a diverse group of people.

The WHO Global Network of Age-friendly Cities and Communities (GNAFCC) was then launched in 2010. It is a broad-scale effort under rapid expansion and now involves a total of 1114 cities and communities in 44 countries [7]. The Global Network serves as a platform for providing connection and support among different communities and cities worldwide to inspire change and to find appropriate innovative and evidence-based solutions. The vision of the Global Network is for every city and community to strive to become increasingly age-friendly [8].

For achieving an age-friendly living environment, a holistic approach is required to enable independent living, inclusion and active participation of older adults in society. The eight domains of the AFC Guide are not mutually exclusive but overlap and support with one another. For example, respect and social inclusion are reflected in the barrier-free access to outdoor spaces and public buildings. Availability of communication and information allow people to connect for social and civic participation.

\section{Applications and Influences}

The built environment refers to human-made physical spaces for living, working and recreation. It ranges in scale from buildings, public and open spaces to neighbourhoods and communities, as well as streets and transportation systems. The built environment has a significant impact on the wellbeing and quality of life of older adults.

\subsection{Age-Friendly Housing and Buildings}

Older adults tend to spend considerably more time at home compared to other age groups [9]. Homes provide older adults with familiar physical setting and emotional affinity in terms of personal experiences and memories [10]. Although ageing may involve deterioration in mobility, visual or hearing abilities and affect cognition and mental capability, it is still desirable for older adults to continue to live in their own homes as long as possible under the notion of 'ageing in place' [11]. The concept of ageing in place is broad, involving personal attachment to place [12]. Attachment to place enables older adults to preserve a sense of identity and independence [13]. Ageing in place does not necessarily imply the continual stay in the same dwelling throughout the later life, but also 
includes the scenario of downsizing or moving to another home with better accessibility to maximise the use of remaining abilities for independent or assisted living [14].

There are a range of housing options for older adults depending on their degree of mobility and levels of impairment, from ordinary houses, apartment units and retirement housing for independent living, extra care housing with required personal support for assisted living, to residential aged care facilities with nursing care for institutional living [15]. In this continuum of housing options, one end is the long-term family home available in the ordinary housing market, whereas another end is the institutional setting of residential aged care facilities for those who are vulnerable with high levels of dependency. Supporting older adults to age in place at their home settings can delay or obviate the need to move to institutional aged care facilities [16].

Housing design with due consideration of the changing needs across the life course caters for ageing in place. The rationale is to support accessibility and facilitate the ease of movement for a wide range of abilities of residents to enable them to live independently, safely and comfortably to minimise the need for subsequent alternation and retrofitting. Age-friendly housing not only provides benefits to residents for ageing well, but also has public value to reduce the resources spent on institutional care facilities [17]. People have spent more time at home than ever before especially during the coronavirus lockdown periods. Under the impact of the COVID-19 pandemic, residential aged care facilities have experienced significant challenges to control infection and minimise disease transmission by enforcing no outside visitor policies and requiring residents to remain in their rooms. However, these measures have had ongoing detrimental effects on the overall health and wellbeing of residents [18]. This highlights the importance of enabling older adults to remain in their own homes as long as possible through age-friendly housing design and technology-supported smart home provisions.

There are different approaches towards increased accessibility and adaptability of housing and buildings such as universal design, inclusive design, design for all and accessible design [19-21]. Despite the lack of consistent terminology, the rationale behind accessibility is quite similar, highlighting the importance of non-discrimination, social inclusion and equity [22]. Design guidelines and accreditation schemes of age-friendly housing have been established in some developed countries, such as Lifetime Homes Design Guide in the UK, Livable Housing Design Guidelines in Australia and the newly developed Homes4Life in Europe.

The idea of the Lifetime Homes Standard originated from the Helen Hamlyn foundation and the Habinteg Housing Association in the late 1980s. It is based on five overarching principles: inclusivity, accessibility, adaptability, sustainability and good value with 16 design criteria to address the changing needs of individuals and families at different stages of life [23]. The Lifetime Homes Design Guide heavily influenced the development of accessibility requirements of the Building Regulations in the UK. Referring to Part M of the Building Regulations, M4(1) is mandatory to set the minimum standards of accessibility for visitable dwellings, while M4(2) and M4(3) are optional for accessible and adaptable dwellings and wheelchair user dwellings, respectively, in which the optional requirement of M4(2) is broadly equivalent to the Lifetime Homes Design Guide. The minimum baseline standard of M4(1) has been criticised to be too low to meet the actual needs [24,25]. A consultation paper was published by the UK government in 2020 to consider how to raise accessibility standards of new homes [26].

The Livable Housing Design Guidelines was developed as an outcome of the National Dialogue on Universal Housing Design which was formed in 2009 consisting of representatives from the government, key stakeholder groups from the ageing, disability and community support sectors and the residential building and property industry. The voluntary guidelines describe 15 liveable design elements which provide guidance on the expected performance to achieve silver, gold or platinum level accreditation. The first seven elements cover the core requirements of the basic silver level accreditation, whereas the platinum level requires the compliance of all 15 elements [27]. According to 
the strategic plan in 2010, the original target was set to require all new houses to comply with silver level by 2020 [28]. However, such voluntary provision was hard to achieve the aspirational target $[29,30]$. Only a low proportion of $5 \%$ of new housing could comply with the guidelines by 2020 [31]. Australia is a signatory to the United Nations Convention on the Rights of Persons with Disabilities (UNCRPD) and has obligations about universal design in housing [32]. Considering the failure to meet the 2020 target, the United Nations Committee (New York, NY, USA) supported the recommendation for a mandated approach through legislation [33]. A majority of building ministers in Australia finally agreed to include minimum accessibility provisions for residential housing and apartments in the National Construction Code 2022 based on the silver level of the Livable Housing Design Guidelines [34].

The Homes4Life project titled 'certified smart and integrated living environments for ageing well' is a new European certification scheme which started in December 2018 after receiving funding from the European Union's Horizon 2020 research and innovation programme (grant agreement no. 826295). The project is run by a multidisciplinary group from five countries (Spain, France, The Netherlands, Italy and Belgium) [35]. By adopting a holistic approach, the evaluation framework of Homes4Life covers six aspects: physical, outdoor access, economic, social, personal and management domains for both new and existing residential buildings. Affordability, privacy and dignity, identity and emotional connectivity are taken into consideration. Compared with the Lifetime Homes Design Guide in the UK and the Livable Housing Design Guidelines in Australia, Home4Life puts a specific focus on smart home technologies. For encouraging digitally enriched dwellings to support home-based independent living, the category of smart readiness is introduced in the Homes4Life certification scheme, covering wireless and wired connectivity, network infrastructure and interoperability, IT infrastructure and application programming interfaces, as well as digital security and data protection [36]. Such comprehensive evaluation framework aims to provide a more responsive age-friendly housing for older adults equipped with digital services (such as telecommunication, telehealth and telecare) to maintain social connectedness, health and wellbeing across the life course, together with home-based monitoring technologies with motion sensors, real-time monitoring and reliable alerts to mitigate risks and ensure their safety and security at home [37-39].

It is important for buildings, especially public facilities, to be easily accessible and conveniently used regardless of the age, ability or status of end users. Features that are considered necessary for age-friendly buildings include ramps, elevators, handrails, slipresistant flooring, seating, accessible public toilets, signage and priority parking bays. Barrier-free buildings address the needs of older adults and empower them to participate in society with inclusion and equity.

\subsection{Age-Friendly Public Spaces and Neighbourhoods/Communities}

Age-friendly housing and buildings are associated with accessible public and outdoor spaces as well as effective social support services and facilities within neighbourhoods to enhance the quality of life and wellbeing of older adults. It is common for older adults to feel lonely and depressed, especially for those who are living alone without a spouse or a partner [40,41]. If public spaces are age-friendly for people to feel safe and comfortable, their willingness to spend time outside will increase. Popular public spaces, such as cafes, parks, shopping malls, libraries, markets and community centres, are regarded as third places, which are different from the first place (home) or the second place (work/school) [42]. Third places foster voluntary social interaction and provide opportunities for older adults to engage in their local communities to form weak and strong social ties with others against isolation and loneliness [43].

There is a close relationship between the built environment, physical activity and health $[44,45]$. Regular physical activity contributes to beneficial health effects against overweight or obesity [45]. Since walking is a key outdoor physical activity of older adults, so the built environment is commonly assessed by its walkability [46]. A neighbourhood 
walkability depends on the land use mix, street connectivity and residential density [47]. An appropriate functional mix integrating residential, commercial and communal uses attracts people to go outside on various schedules. Street connectivity correlates with the street pattern and block size and is an indicator of how accessible a neighbourhood is. Residential density refers to the dense concentration of people, which is regarded as an important condition for 'flourishing city life' and 'a visibly lively public street life' [48]. Older adults living in mixed-use, better connected and more compact neighbourhoods are more likely to be active as the walking distances between destinations and homes are shortened [49]. Other factors that affect the walkability of the built environment include pedestrian safety from vehicular traffic with lower speed limits and more road crossings, connectivity of pedestrian facilities, public safety from crime and violence, trees and vegetation for shading and amenity, adequate lighting for illumination, distinctive signage for wayfinding, user-friendly street furniture and inclusive urban design with barrier-free access [50-52].

The notion of ageing in place extends from age-friendly housing to neighbourhoods and communities. Ageing in place encourages older adults with some degree of independent living ability to remain in their familiar surroundings for longer to maintain their routines, habits and ongoing social connections with others [53]. It is beneficial for older adults to stay in familiar neighbourhoods and communities in their later life, which provides them with a sense of security and belonging. Secure neighbourhoods encourage older adults to spend time outside in confidence to participate in various activities, which enhance cross-generational social encounters. The strategy of lifetime homes and lifetime neighbourhoods was launched in the UK in 2008 to promote a range of affordable and accessible housing choices, to enable residents to connect with other people at the community level and to empower them to develop lifetime neighbourhoods [54]. The six key components of lifetime neighbourhoods are: housing, the built and natural environments, services and amenities, social networks/wellbeing, accessibility and resident empowerment [55]. Similarly, the Lifelong Communities Handbook: Creating Opportunities for Lifelong Living was published in 2009 in the US [56]. The seven principles of lifelong communities are: diversity of dwelling types, neighbourhood retail and services, pedestrian access and transit, connectivity, social interaction, healthy living and consideration for existing residents. An enabling built environment with associated social infrastructure supports health and wellbeing over an individual's lifetime [57].

\subsection{Age-Friendly Transportation}

Walkable age-friendly neighbourhoods and communities provide a safe and wellconnected pedestrian network with various transport modes. The availability and accessibility of safe, frequent and reliable public transport facilitates older adults to get around and enhance their mobility. Service quality and travel safety perceptions affect the perceived accessibility of public transport [58]. The age-friendly design of train stations, tram and bus stops is equipped with seating benches, shelters and adequate lighting. The provisions of ramps, elevators and escalators to platforms and low-floor boarding onto buses offer ease of access. Priority seats on public transport encourage passengers to offer seats to older adults and other users in need. The affordability of public transport is also a factor to be considered. In some countries, older adults are entitled to concession fares or even free access to public transport such as buses, trains and trams. This allows them to access to health-related services and communal facilities. Travelling by public transport provides opportunities for social encounters and enables the enjoyment of 'the spectacle of others' interactions and the sense of life going on' [59]. Mobility enhancement through the use of public transport leads to an increase in the quality of life of older adults and a reduction in social exclusion [60].

In addition to walkability, the built environment can be assessed by its bikeability or level of bicycle-friendliness [61]. Cycling is an environmentally sustainable transportation mode to reduce vehicle use and improve air quality. It is also a form of physical activity that 
contributes to public health as part of an active ageing agenda [62]. Factors affecting the cycling participation of older adults include segregation from vehicular traffic, safety, other cyclists' behaviour, convenience and availability of the relevant infrastructure [63]. Electric bicycles (also called e-bikes) are increasingly popular and stimulate cycling participation. E-bikes are battery-driven and enable users to ride longer distances in comfort with reduced effort [64]. From the planning perspective, it is important to design and provide well-connected bike tracks (or cycling trails) to stimulate transportation cycling among older adults.

For those older adults living in suburbs and remote areas with a lack of public transport, car ownership is associated with their mobility and wellbeing closely. The continuing decline in cognitive, sensory and physical abilities of older adults may cause slow reaction times, poor eyesight, hearing impairment, attention difficulty and memory loss, resulting in driving risks and other safety concerns [65]. Driving cessation is a difficult and challenging issue for older adults, especially for those who have been used to driving. The transition to a non-driving status leads to a sense of loss of independence and the feeling of depression [66,67]. The emergence of fully-autonomous or driverless vehicles may be a solution to offer stress-free door-to-door mobility and increase travel opportunities for older adults, but the popularity of this emerging transport technology depends on its accessibility, reliability and affordability $[68,69]$.

\section{Conclusions and Prospects}

Facing population ageing and urbanisation, there is a pressing need to create agefriendly built environments for people to have fair and just opportunities to continue their lifestyles and participate in their communities to enhance their quality of life and wellbeing regardless of their age or ability. Ageing in place is promoted for older adults to stay in their familiar living environment to maintain social engagement at the neighbourhood and community levels. It is beneficial for them to live at home as long as possible to minimise the need of staying in institutional setting of aged care facilities. For achieving ageing in place, accessible, adaptable and affordable housing options should be available and smart technologies are highly preferrable to be integrated in housing design to support independent living, assisted living and various digital services. Although there are voluntary design guidelines of age-friendly housing and buildings, there is a lack of incentives for private developers to put additional resources to address the needs of the ageing population. Therefore, the existing voluntary design guidelines are recommended to be replaced by regulatory approaches through legislation to benefit people of all ages and abilities. Government and local councils should be more proactive in enhancing the age-friendliness of built environment as exemplars.

Built environments are often designed and planned by professional people with limited diversity, but not all voices are heard, especially those from marginalised groups. Co-design is a possible way to engage with older adults as collaborators and partners in which their contribution and participation are valued and acknowledged. Despite the challenge of embedding co-design practice into design processes and procedures involving potential time and cost implications, it is worthwhile to take into due consideration of various views from different stakeholders to ensure that their needs are addressed in the design outcome. In addition to planning and design, the participation of older adults in other decision-making processes should be widened to empower them to share their valuable knowledge and experience in enhancing the overall age-friendliness of their neighbourhoods and communities.

The age-friendly built environment is inclusive and accessible through tangible physical infrastructure, building design, public and outdoor open space arrangement and transportation provisions. Other domains of AFC Guide cover intangible aspects, including respect and social inclusion, community support and communication. Both tangible and intangible aspects are complimentary with one another. It is of paramount importance to take a holistic comprehensive approach to optimise both physical and social environments with supportive service provisions to accommodate the growing ageing population. 
The idea of age-friendliness has successfully attracted many cities around the world to join the GNAFCC, which seems to be a distinctive branding strategy for cities. Compared with high-sounding commitment, it is crucial to implement age-friendly initiatives and programs in a sustainable manner at the national and state government levels, as well as local communities and neighbourhoods, to address the changing needs across the life course.

\section{Lists of Design Standards and Guidelines}

\subsection{Age-Friendly Housing and Buildings}

- Accessibility of Housing: A Handbook of Inclusive Affordable Housing Solutions for Persons with Disabilities and Older Persons [70];

- $\quad$ ADA Standards for Accessible Design;

- ANSI A117.1 Accessible and Usable Buildings and Facilities;

- $\quad$ AS 1428.1 Design for Access and Mobility-General Requirements for Access-New Building Work;

- AS 1428.2 Design for Access and Mobility-Enhanced and Additional RequirementsBuildings and Facilities;

- AS 4299 Adaptable Housing;

- $\quad$ BS 4467 Guide to Dimensions in Designing for Elderly People;

- BS 8300-2 Design of an Accessible and Inclusive Built Environment-Part 2: BuildingsCode of Practice;

- $\quad$ BS 9266 Design of Accessible and Adaptable General Needs Housing-Code of Practice;

- Design Principles for Extra Care Housing [15]

- Designing for Inclusion and Independence: An Explanatory Guide to support the Briefing and Design of Accessible Housing [71];

- Homes4Life: Certification for Ageing in Place [35];

- Housing Enabler Screening Tool [72];

- Housing for Life [73];

- ICC A117.1 Standard for Accessible and Usable Buildings and Facilities;

- ISO/IEC Guide 71 Guide for Addressing Accessibility in Standards;

- $\quad$ ISO TR 22,411 Ergonomics Data for Use in the Application of ISO/IEC Guide 71

- $\quad$ Lifetime Homes Design Guide [23];

- $\quad$ Livable Housing Design Guidelines [27];

- Lifemark Design Standards Handbook [74];

- $\quad$ FlexHousing: Building Adaptable Housing [75];

- $\quad$ Older Persons Housing Design: A European Good Practice Guide [76];

- Universal Design for Houses [77];

- Universal Housing Design Guidelines [78];

- Wheelchair Housing Design Guide [79].

\subsection{Age-Friendly Public Spaces and Neighbourhoods/Communities}

- $\quad$ BIP 2228 Inclusive Urban Design: A Guide to Creating Accessible Public Spaces;

- $\quad$ BS 8300-1 Design of an Accessible and Inclusive Built Environment-Part 1: External Environment-Code of Practice;

- DD ENV 14383-2 Prevention of Crime-Urban Planning and Design-Part 2: Urban Planning;

- $\quad$ Enabling Inclusive Cities: Tool Kit for Inclusive Urban Development [80];

- $\quad$ Good Practices of Accessible Urban Development [81];

- $\quad$ Lifelong Communities Handbook: Creating Opportunities for Lifelong Living [56]

- $\quad$ Lifetime Neighbourhoods [55];

- Livable Communities: An Evaluation Guide [82];

- Neighbourhoods for Life: A Checklist of Recommendations for Designing Dementiafriendly Outdoor Environments [83];

- The Inclusive Imperative: Towards Disability-inclusive and Accessible Urban Development: Key Recommendations for an Inclusive Urban Agenda [84]. 


\subsection{Age-Friendly Transportation}

- Connecting Transportation \& Health: A Guide to Communication \& Collaboration. [85];

- Guidelines: Equivalent Access under the Disability Standards for Accessible Public Transport 2002 (Cth) [86];

- Improving Transport Accessibility for All: Guide to Good Practice [87];

- Improving Accessibility to Transport for People with Limited Mobility (PLM): A Practical Guidance Note [88];

- Inclusive Mobility: Making Transport Accessible for Passengers and Pedestrians [89];

- The Whole Journey: A Guide for Thinking Beyond Compliance to Create Accessible Public Transport Journeys [90];

- Transit Universal Design Guidelines: Principles and Best Practices for Implementing Universal Design in Transit [91].

Author Contributions: Conceptualization, H.-W.C.; writing-original draft preparation, H.-W.C. and E.J.; writing-review and editing, H.-W.C. and E.J. Both authors have read and agreed to the published version of the manuscript.

Funding: This research received no external funding.

Acknowledgments: The authors would like to express their thanks to anonymous reviewers for their constructive comments, the Lead Collection Editor, Masa Noguchi and other collection editors for the topical collection 'Encyclopedia of ZEMCH Research and Development'.

Conflicts of Interest: The authors declare no conflict of interest.

Entry Link on the Encyclopedia Platform: https:/ / encyclopedia.pub/14047.

\section{References}

1. United Nations. World Population Prospects 2019; UN Department of Economic and Social Affairs Population Division: New York, NY, USA, 2019.

2. WHO. Global Age-Friendly Cities: A Guide; World Health Organization: Geneva, Switzerland, 2007.

3. United Nations. Resolution 33/52: World Assembly on the Elderly (14 December 1978). Available online: https://undocs.org/ en/A/RES/33/52 (accessed on 22 July 2021).

4. United Nations. Report of the World Assembly on Aging: Vienna, 26 July to 6 August 1982. Available online: https:/ /www.un. org/esa/socdev/ageing/documents/Resources/VIPEE-English.pdf (accessed on 24 July 2021).

5. United Nations. Report of the Second World Assembly on Ageing: Madrid, 8-12 April 2002. Available online: https://www.un. org/en/events / pastevents/ageing_assembly2.shtml (accessed on 24 July 2021).

6. WHO. Active Ageing: A Policy Framework; World Health Organization: Geneva, Switzerland, 2002.

7. About the Global Network for Age-Friendly Cities and Communities. Available online: https://extranet.who.int/ agefriendlyworld/who-network/ (accessed on 26 March 2021).

8. WHO. The Global Network for Age-Friendly Cities and Communities: Looking Back over the Last Decade, Looking Forward to the Next; World Health Organization: Geneva, Switzerland, 2018.

9. Oswald, F.; Hieber, A.; Wahl, H.-W.; Mollenkopf, H. Ageing and person-environment fit in different urban neighbourhoods. Eur. J. Ageing 2005, 2, 88-97. [CrossRef]

10. Stones, D.; Gullifer, J. 'At home it's just so much easier to be yourself': Older adults' perceptions of ageing in place. Ageing Soc. 2016, 36, 449-481. [CrossRef]

11. Wiles, J.L.; Leibing, A.; Guberman, N.; Reeve, J.; Allen, R.E. The meaning of "aging in place" to older people. Gerontologist 2012, 52, 357-366. [CrossRef]

12. Pani-Harreman, K.E.; Bours, G.J.; Zander, I.; Kempen, G.I.; van Duren, J.M. Definitions, key themes and aspects of 'ageing in place': A scoping review. Ageing Soc. 2020, 41, 2026-2059. [CrossRef]

13. Peace, S.; Holland, C.; Kellaher, L. 'Option recognition' in later life: Variations in aging in place. Ageing Soc. 2011, 31, 734-757. [CrossRef]

14. Boldy, D.; Grenade, L.; Lewin, G.; Karol, E.; Burton, E. Older people's decisions regarding 'ageing in place': A Western Australian case study. Australas. J. Ageing 2011, 30, 136-142. [CrossRef]

15. Housing LIN. Design Principles for Extra Care Housing; Housing Learning and Improvement Network: London, UK, 2020.

16. Grimmer, K.; Kay, D.; Foot, J.; Pastakia, K. Consumer views about aging-in-place. Clin. Interv. Aging 2015, $10,1803-1811$. [CrossRef] [PubMed] 
17. Sinclair, S.; de Silva, A.; Kopanidis, F. Exploring the Economic Value Embedded in Housing Built to Universal Design Principles: Bridging the Gap between Public Placemaking and Private Residential Housing; Centre for Urban Research, RMIT University: Melbourne, Australia, 2020.

18. Dawson, A.; Berta, W.B.; Morton-Chang, F.; Palmer, L.; Quirke, M. Long term care and the coronavirus pandemic: A new role for environmental design in a changing context. In World Alzheimer Report 2020—Design, Dignity, Dementia: Dementia-Related Design and the Built Environment; Fleming, R., Zeisel, J., Bennett, K., Eds.; Alzheimer's Disease International: London, UK, 2020; Volume 1, pp. 238-245.

19. Carr, K.; Weir, P.L.; Azar, D.; Azar, N.R. Universal design: A step toward successful aging. J. Aging Res. 2013, 2013, 324624. [CrossRef]

20. Hall, T. Inclusive design and elder housing solutions for the future. NAELA J. 2015, 11, 61-72.

21. Houston, A.; Mitchell, W.; Ryan, K.; Hullah, N.; Hitchmough, P.; Dunne, T.; Dunne, J.; Edwards, B.; Marshall, M.; Christie, J. Accessible design and dementia: A neglected space in the equality debate. Dementia 2020, 19, 83-94. [CrossRef]

22. Persson, H.; Åhman, H.; Yngling, A.A.; Gulliksen, J. Universal design, inclusive design, accessible design, design for all: Different concepts-One goal? On the concept of accessibility-Historical, methodological and philosophical aspects. Univers. Access Inf. Soc. 2015, 14, 505-526. [CrossRef]

23. Goodman, C. Lifetime Homes Design Guide; IHS BRE Press: Bracknell, UK, 2011.

24. House of Commons Women and Equalities Committee. Building for Equality: Disability and the Built Environment; House of Commons Women and Equalities Committee: London, UK, 2017.

25. RIBA. A Home for the Ages: Planning for the Future with Age-Friendly Design; RIBA: London, UK, 2019.

26. Ministry of Housing, Communities and Local Government. Raising Accessibility Standards for New Homes: A Consultation Paper; Ministry of Housing: London, UK, 2020.

27. Livable Housing Australia. Livable Housing Design Guidelines, 4th ed.; Livable Housing Australia: Forest Lodge, Australia, 2017.

28. Department of Social Services, Australian Government. National Dialogue on Universal Housing Design-Strategic Plan; Department of Social Services, Australian Government: Canberra, Australia, 2010.

29. Bringolf, J. Barriers to Universal Design in Housing; University of Western Sydney: Sydney, Australia, 2011.

30. Ward, M.; Franz, J.; Adkins, B. Livable Housing Design: The voluntary provision of inclusive housing in Australia. J. Soc. Incl. 2014, 5, 43-60. [CrossRef]

31. Australian Civil Society. Disability Rights Now 2019: Australian Civil Society Shadow Report to the United Nations Committee on the Rights of Persons with Disabilities: UN CRPD Review 2019; Australian Civil Society: Canberra, Australia, 2019.

32. Ward, M. Universal Design in Housing: Reporting on Australia's Obligations to the UNCRPD. In Proceedings of the 4th Australian Universal Design Conference, Melbourne, Australia, 17-18 May 2021.

33. UN Committee on the Rights of Persons with Disabilities. Concluding Observations on the Combined Second and Third Periodic Reports of Australia; UN Committee on the Rights of Persons with Disabilities: New York, NY, USA, 2019.

34. Department of Industry, Science, Energy and Resources, Australian Government. Building Ministers' Meeting: Communiqué April 2021. Available online: https:/ / www.industry.gov.au/news/building-ministers-meeting-communique-april-2021 (accessed on 4 June 2021).

35. Homes4Life. Homes4Life: Certification for Ageing in Place. Available online: http://www.homes4life.eu/ (accessed on 30 May 2021).

36. Homes4Life. D4.4—Technical Reference Framework—Final Version; Homes4Life: Dubai, United Arab Emirates, 2021.

37. Decorme, R.; Urra, S.; Nicolas, O.; Dantas, C.; Hermann, A.; Peñaloza, G.H.; García, F.Á.; Ollevier, A.; Vassiliou, M.C.; van Staalduinen, W. Sustainable Housing Supporting Health and Well-Being. Proceedings 2020, 65, 12. [CrossRef]

38. van Kasteren, Y.; Bradford, D.; Zhang, Q.; Karunanithi, M.; Ding, H. Understanding smart home sensor data for ageing in place through everyday household routines: A mixed method case study. JMIR mHealth uHealth 2017, 5, e52. [CrossRef]

39. Carnemolla, P. Ageing in place and the internet of things-How smart home technologies, the built environment and caregiving intersect. Vis. Eng. 2018, 6, 7. [CrossRef]

40. Savikko, N.; Routasalo, P.; Tilvis, R.S.; Strandberg, T.E.; Pitkälä, K.H. Predictors and subjective causes of loneliness in an aged population. Arch. Gerontol. Geriatr. 2005, 41, 223-233. [CrossRef] [PubMed]

41. Sundström, G.; Fransson, E.; Malmberg, B.; Davey, A. Loneliness among older Europeans. Eur. J. Ageing 2009, 6, 267-275. [CrossRef] [PubMed]

42. Oldenburg, R. The Great Good Place: Cafés, Coffee Shops, Community Centers, Beauty Parlors, General Stores, Bars, Hangouts, and How They Get You through the Day; Paragon House: New York, NY, USA, 1989.

43. Alidoust, S.; Bosman, C.; Holden, G. Planning for healthy ageing: How the use of third places contributes to the social health of older populations. Ageing Soc. 2018, 39, 1459-1484. [CrossRef]

44. Sallis, J.F. Measuring physical activity environments: A brief history. Am. J. Prev. Med. 2009, 36, S86-S92. [CrossRef]

45. Frank, L.D.; Andresen, M.A.; Schmid, T.L. Obesity relationships with community design, physical activity, and time spent in cars. Am. J. Prev. Med. 2004, 27, 87-96. [CrossRef]

46. Borst, H.C.; de Vries, S.I.; Graham, J.M.; van Dongen, J.E.; Bakker, I.; Miedema, H.M. Influence of environmental street characteristics on walking route choice of elderly people. J. Environ. Psychol. 2009, 29, 477-484. [CrossRef] 
47. Van Holle, V.; Van Cauwenberg, J.; Van Dyck, D.; Deforche, B.; Van de Weghe, N.; De Bourdeaudhuij, I. Relationship between neighborhood walkability and older adults' physical activity: Results from the Belgian Environmental Physical Activity Study in Seniors (BEPAS Seniors). Int. J. Behav. Nutr. Phys. Act. 2014, 11, 110. [CrossRef]

48. Jacobs, J. The Death and Life of Great American Cities; Vintage Books: New York, NY, USA, 1961.

49. Frank, L.D.; Schmid, T.L.; Sallis, J.F.; Chapman, J.; Saelens, B.E. Linking objectively measured physical activity with objectively measured urban form: Findings from SMARTRAQ. Am. J. Prev. Med. 2005, 28, 117-125. [CrossRef]

50. Jacobs, A.B. Great Streets; MIT Press: Cambridge, MA, USA, 1993.

51. Crowe, T.D. Crime Prevention through Environmental Design; Elsevier: Amsterdam, The Netherlands, 2013.

52. Davoudian, N. Urban Lighting for People: Evidence-Based Lighting Design for the Built Environment; RIBA Publishing: London, UK, 2019.

53. Houben, P. Changing housing for elderly people and co-ordination issues in Europe. Hous. Stud. 2001, 16, 651-673. [CrossRef]

54. DCLG. Lifetime Homes, Lifetime Neighbourhoods: A National Strategy for Housing in an Ageing Society; Department for Communities and Local Government: London, UK, 2008.

55. Bevan, M.; Croucher, K. Lifetime Neighbourhoods; Department for Communities and Local Government: London, UK, 2011.

56. Atlanta Regional Commission. Lifelong Communities Handbook: Creating Opportunities for Lifelong Living; Atlanta Regional Commission: Atlanta, Georgia, 2009.

57. Keyes, L.; Rader, C.; Berger, C. Creating communities: Atlanta's lifelong community initiative. Phys. Occup. Ther. Geriatr. 2011, 29,59-74. [CrossRef]

58. Friman, M.; Lättman, K.; Olsson, L.E. Public transport quality, safety, and perceived accessibility. Sustainability 2020, $12,3563$. [CrossRef]

59. Green, J.; Jones, A.; Roberts, H. More than A to B: The role of free bus travel for the mobility and wellbeing of older citizens in London. Ageing Soc. 2014, 34, 472-494. [CrossRef]

60. Rye, T.; Mykura, W. Concessionary bus fares for older people in Scotland-are they achieving their objectives? J. Transp. Geogr. 2009, 17, 451-456. [CrossRef]

61. Krenn, P.J.; Oja, P.; Titze, S. Development of a bikeability index to assess the bicycle-friendliness of urban environments. Open J. Civ. Eng. 2015, 5, 451. [CrossRef]

62. Black, P.; Street, E. The power of perceptions: Exploring the role of urban design in cycling behaviours and healthy ageing. Transp. Res. Procedia 2014, 4, 68-79. [CrossRef]

63. Winters, M.; Sims-Gould, J.; Franke, T.; McKay, H. “I grew up on a bike": Cycling and older adults. J. Transp. Health 2015, 2, 58-67. [CrossRef]

64. Van Cauwenberg, J.; De Bourdeaudhuij, I.; Clarys, P.; De Geus, B.; Deforche, B. Older adults' environmental preferences for transportation cycling. J. Transp. Health 2019, 13, 185-199. [CrossRef]

65. Anstey, K.J.; Wood, J.; Lord, S.; Walker, J.G. Cognitive, sensory and physical factors enabling driving safety in older adults. Clin. Psychol. Rev. 2005, 25, 45-65. [CrossRef]

66. Adler, G.; Rottunda, S. Older adults' perspectives on driving cessation. J. Aging Stud. 2006, 20, 227-235. [CrossRef]

67. Deka, D. The effect of mobility loss and car ownership on the feeling of depression, happiness, and loneliness. J. Transp. Health 2017, 4, 99-107. [CrossRef]

68. Kovacs, F.S.; McLeod, S.; Curtis, C. Aged mobility in the era of transportation disruption: Will autonomous vehicles address impediments to the mobility of ageing populations? Travel Behav. Soc. 2020, 20, 122-132. [CrossRef]

69. Zandieh, R.; Acheampong, R.A. Mobility and healthy ageing in the city: Exploring opportunities and challenges of autonomous vehicles for older adults' outdoor mobility. Cities 2021, 112, 103135. [CrossRef]

70. UN Habitat. Accessibility of Housing: A Handbook of Inclusive Affordable Housing Solutions for Persons with Disabilities and Older Persons; UN-Habitat: Nairobi, Kenya, 2014.

71. Summer Housing. Designing for Inclusioin and Independence: An Explanatory Guide to Support the Briefing and Design of Accessible Housing. Available online: https://summerhousing.org.au/designing-for-inclusion-and-independence/ (accessed on 29 July 2021).

72. Iwarsson, S.; Slaug, B. The Housing Enabler Screening Tool. Available online: http:/ / www.enabler.nu/ (accessed on 30 May 2021).

73. Master Buildrs Association of the ACT. Housing for Life; Master Buildrs Association of the ACT: Lyneham, Australia, 2001.

74. Lifetime Design Limited. Lifemark Design Standards Handbook; Lifetime Design Limited: Auckland, New Zealand, 2016.

75. Canada Mortgage and Housing Corporation. FlexHousingTM: Building Adaptable Housing; Canada Mortgage and Housing Corporation: Ottawa, ON, Canada, 2000.

76. Emilia-Romagna Territorial Economic Development S.p.A. (ERVET); Blekinge Institute of Technology—Karlskrona University; Brighton and Hove City Council; FAMCP Federazione Aragonese di Municipalità; Györ City Council. Older Persons' Housing Design: A European Good Practice Guide; Wel-hops Network: Bologna, Italy, 2007.

77. BRANZ. Universal Design for Houses. Available online: http://www.buildmagazine.org.nz/assets/PDF/Build_168_Universal_ Design_Supplement.pdf (accessed on 29 July 2021).

78. Landcom. Universal Housing Design Guidelines; Landcom: Parramatta, Australia, 2008.

79. Habinteg Housing Association. Wheelchair Housing Design Guide, 3rd ed.; RIBA Publishing: London, UK, 2018.

80. Asian Development Bank. Enabling Inclusive Cities: Tool Kit for Inclusive Urban Development; Asian Development Bank: Manila, Philippines, 2017. 
81. United Nations. Good Practices of Accessible Urban Development; United Nations: New York, NY, USA, 2016.

82. AARP. Livable Communities: An Evaluation Guide; American Assocation of Retired Persons: Washington, DC, USA, 2005.

83. Mitchell, L.; Burton, E.; Raman, S. Neighbourhoods for Life: A Checklist of Recommendations for Designing Dementia-Friendly Outdoor Environments; Housing Corporation: London, UK, 2004.

84. Disability Inclusive and Accessible Urban Development Network. The Inclusion Imperative: Towards Disability-Inclusive and Accessible Urban Development_Key Recommendations for an Inclusive Urban Agenda; Disability Inclusive and Accessible Urban Development Network: New York, NY, USA, 2016.

85. Steedly, A.; Townsend, T.; Huston, B.; Lane, L.B.; Danley, C. Connecting Transportation \& Health: A Guide to Communication \& Collaboration. Available online: http:/ / onlinepubs.trb.org/onlinepubs/nchrp/docs/NCHRP25-25Task105/NCHRP25-25 Task105Guidebook.pdf (accessed on 29 July 2021).

86. Australian Human Rights Commission. Guidelines: Equivalent Access under the Disability Standards for Accessible Public Transport 2002 (Cth); Australian Human Rights Commission: Sydney, Australia, 2020.

87. European Conference of Ministers of Transport. Improving Transport Accessibility for All: Guide to Good Practice; OECD Publications Service: Paris, France, 2006.

88. World Bank. Improving Accessibility to Transport for People with Limited Mobility (PLM): A Practical Guidance Note; World Bank: Washington, DC, USA, 2013.

89. Department for Transport, U.G. Inclusive Mobility: Making Transport Accessible for Passengers and Pedestrians. Available online: https: / /www.gov.uk/government/publications/inclusive-mobility (accessed on 6 June 2021).

90. Department of Infrastructure and Regional Development, A.G. The Whole Journey: A Guide for Thinking beyond Compliance to Create Accessible Public Transport Journeys; Department of Infrastructure and Regional Development, A.G.: Canberra, Australia, 2017.

91. American Public Transportation Association. Transit Universal Design Guidelines: Principles and Best Practices for Implementing Universal Design in Transit; American Public Transportation Association: Washington, DC, USA, 2020. 